\title{
Expression of Plasmids Coding for Colonization Factor Antigen II (CFA/II) and Enterotoxin Production in Escherichia coli
}

\author{
By P. MULlanY, ${ }^{1}$ A. M. FIELD, ${ }^{2}$ M. M. MCCONNELL, ${ }^{1 *}$ \\ S. M. SCOTLAND, ${ }^{1}$ H. R. SMITH ${ }^{1}$ AND B. ROWE ${ }^{1}$ \\ ${ }^{1}$ Division of Enteric Pathogens and ${ }^{2}$ Virus Reference Laboratory, Central Public Health \\ Laboratory, Colindale Avenue, London NW9 5HT, U.K.
}

(Received 20 May 1983; revised 12 July 1983)

\begin{abstract}
Two plasmids transferred from enterotoxigenic Escherichia coli (ETEC) of serotype O6. H16 and biotypes $\mathrm{A}$ and $\mathrm{C}$ coded for mannose-resistant haemagglutination (MRHA) and production of heat-stable enterotoxin (ST) and heat-labile enterotoxin (LT). Both plasmids were nonautotransferring being mobilized most efficiently by the R plasmid R100-1. They were similar in their genetic properties being incompatible with each other and plasmids of the Inc group FI. The wild-type strains produced the colonization factor antigen II (CFA/II) which was made up of different coli surface antigens (CS). The biotype A strains produced CS1 and CS3 while the biotype $\mathrm{C}$ strains produced CS2 and CS3. These three antigens have the ability to cause MRHA. When plasmids coding for MRHA were transferred to K12 strains, the degree of haemagglutination was markedly reduced and only CS3 was produced. When both plasmids were transferred back into biotype A strains, good MRHA was restored and the strains produced CS1 and CS3. In a biotype C strain CS2 and CS3 were formed. The production of the antigens was compared by enzyme-linked immunosorbent assay (ELISA). The strains were also examined by electron microscopy where it was found that CS1 and CS2 were fimbrial antigens while CS3 was not.
\end{abstract}

\section{INTRODUCTION}

Enterotoxigenic Escherichia coli (ETEC) can cause diarrhoeal disease in both humans and animals by colonizing the small intestine and producing enterotoxins. In many ETEC strains the adhesion to the intestinal mucosa has been found to be mediated by specific fimbrial antigens. Four antigens K88, K99, F41 and 987P have been identified on strains of animal origin (for review see Gaastra \& de Graaf, 1982), while in ETEC isolated from humans the colonization factor antigens I and II (CFA/I and CFA/II) have been described (Evans et al., 1975; Ørskov \& Ørskov, 1977; Evans \& Evans, 1978; Cravioto et al., 1982; Smyth, 1982). The fimbrial antigen E8775 has also been demonstrated in some ETEC of human origin but its role in intestinal colonization has not yet been confirmed (Thomas et al., 1982).

CFA/II was originally described as a heat-labile colonization factor antigen produced by enterotoxigenic $E$. coli of serogroups $\mathrm{O} 6$ and $\mathrm{O} 8$. It mediated mannose-resistant haemagglutination (MRHA) of bovine erythrocytes at $4{ }^{\circ} \mathrm{C}$ and was fimbrial in nature. When MRHA ${ }^{+}$ ETEC were examined by immunodiffusion tests using a specific CFA/II antiserum only a single precipitin line was observed (Evans \& Evans, 1978). When other workers examined ETEC of serogroup O6 for the presence of CFA/II in a similar way, more than one line was detected (Cravioto et al., 1982; Smyth, 1982).

Abbreviations: CFA, colonization factor antigen; CS, coli surface antigen; ETEC, enterotoxigenic Escherichia coli; LT, heat labile enterotoxin; MRHA, mannose-resistant haemagglutination; PT, PBS containing $0.02 \%$ Tween 20; PTF, PBS containing 0.01\% Tween 20 and $0.5 \%$ foetal calf serum; ST, heat stable enterotoxin. 
O6. H16 strains have been divided into seven types according to biochemical tests (Scotland $e t$ al., 1977). Antisera were prepared against different biotypes of MRHA ${ }^{+} \mathrm{O} 6 . \mathrm{H} 16$ or $\mathrm{O}^{-\mathrm{H}^{-}}$ strains and absorbed with the corresponding $\mathrm{MRHA}^{-}$derivative. Using these antisera to test O6. H16 strains of different biotypes three distinct precipitin lines could be demonstrated. In most strains the antigen designated CFA/II component 3 (Cravioto et al., 1982) or coli surface associated antigen 3 (CS3) (Smyth, 1982) was produced together with a second antigen, CFA/II component 1 or 2 (CS1 or CS2). A few strains made only CS2. CS1 production was always associated with 06 . H16 biotype A strains while CS2 was produced by strains of biotypes B, C and F (Cravioto et al., 1982; Smyth, 1982). Strains belonging to serogroups other than O6 were also examined and found only to produce CS3 (Cravioto et al., 1982) with the exception of one O139.H28 strain which produced CS1 and CS3 (M. M. McConnell \& S. M. Scotland, unpublished). In this paper, CFA/II is used as a general term to describe the three antigens CS1, CS2 and CS3. A CFA/II producing strain may express CS1 and CS3, CS2 and CS3 or CS2 or CS3 only. No wild-type strains producing only CS1 have been described. From an examination of immunodiffusion pictures and because a precipitin line was found in 08, O80 and O85 strains it is clear that CFA/II as defined by Evans \& Evans (1978) corresponds to CS3 (component 3) (Cravioto et al., 1982; Smyth, 1982).

Strains producing CFA/II have so far been found in the following serogroups: O6, 08, 078, O80, O85, O115, 0139 and O168 (Evans \& Evans, 1978; Cravioto et al., 1982; Smyth, 1982; Thomas \& Rowe, 1982). Some of these strains cause MRHA of human as well as bovine erythrocytes (Evans \& Evans, 1978; Cravioto et al., 1982; Smith et al., 1983).

Production of CFA/II components has been shown to be plasmid mediated and linked to the production of heat-stable enterotoxin (ST) and heat-labile enterotoxin (LT) in strains of serogroups $\mathrm{O6}$ and $\mathrm{O85}$. A CFA/II-ST-LT plasmid was introduced into E. coli $\mathrm{K} 12$ from one of the $06 . \mathrm{H} 16$ strains by cotransformation with a drug-resistance plasmid; the $\mathrm{K} 12$ transformant carried a plasmid of molecular weight $60 \times 10^{6}$ (Penaranda et al., 1980). CFA/II-ST-LT plasmids have also been mobilized from three $\mathrm{O6}$. $\mathrm{H} 16$ strains belonging to biotype $\mathrm{B}$ or $\mathrm{C}$ which originally produced CS2 and CS3. After transfer of the plasmids to K12, only CS3 was expressed. However, when the same plasmid was transferred back into an O6. H16 biotype C strain both CS2 and CS3 were produced (Smith et al., 1983).

In this paper we describe the transfer of a CFA/II plasmid from an O6. H16 strain of biotype A. The properties of this plasmid were compared with those of one of the plasmids isolated from an O6.H16 biotype C strain. Both plasmids were transferred from K12 into a number of different $E$. coli hosts and the expression of the CS antigens was examined by MRHA, immunodiffusion and enzyme-linked immunosorbent assay (ELISA). Some of the strains carrying CFA/II plasmids were examined by electron microscopy.

\section{METHODS}

Bacterial strains and plasmids. The wild-type ETEC strains producing CFA/II are listed in Table 1; these strains have been described previously (Cravioto et al., 1982). Table 1 also shows non-enterotoxigenic strains used as recipients in experiments to study the expression of CFA/II.

The standard plasmids used in transfer and incompatibility experiments are listed in Table 2.

Tests for resistance to antibacterial drugs. Strains were tested for drug resistance by the methods of Anderson \& Threlfall (1974).

Enterotoxin tests. ST was detected by the infant mouse test (Dean et al., 1972). The production of LT was examined with Y1 adrenal cells (Donta et al., 1974) and CHO cells (Guerrant et al., 1974) in tissue culture.

Mannose-resistant and mannose-sensitive haemagglutination (MSHA). MRHA tests were performed as described by Cravioto et al. (1982). Blood samples from individual calves were supplied by Tissue Culture Services Ltd.

Strains to be tested for type 1 fimbriae which cause MSHA were grown statically in nutrient broth and were subcultured at least three times before being tested for their ability to agglutinate washed guinea pig erythrocytes at a concentration of $3 \%$ in saline with and without $0.5 \%$ mannose at room temperature (Duguid et al., 1955).

Immunodiffusion tests $(I D)$. Antisera were prepared in rabbits against PB-176 (E. coli O6. H16 biotype A which produces CS1 and CS3), E4833 (E. coli O6. H16 biotype B which produces CS2 and CS3) and E2047/69 (E. coli O6.H16 biotype B which produces only CS2). Antisera for CS1 and CS3, or CS2 and CS3 or CS2 only were obtained by absorption of whole sera with spontaneous $\mathrm{CFA} / \mathrm{II}^{-}$variants detected as $\mathrm{MRHA}^{-}$variants of each 
Table 1. Properties of E. coli strains

\begin{tabular}{|c|c|c|c|c|c|c|c|c|}
\hline \multirow[b]{2}{*}{ Strain no. } & \multirow[b]{2}{*}{ Origin } & \multirow[b]{2}{*}{ Serotype } & \multirow[b]{2}{*}{ Biotype } & \multicolumn{2}{|c|}{$\begin{array}{l}\text { Enterotoxin } \\
\text { production }\end{array}$} & \multicolumn{3}{|c|}{$\begin{array}{l}\text { Coli surface } \\
\text { antigen }\end{array}$} \\
\hline & & & & ST & LT & CS1 & $\mathrm{CS} 2$ & CS3 \\
\hline E9188 & Japan, 1977 & O6.H16 & $\mathbf{A}$ & + & + & + & - & + \\
\hline $58 \mathrm{R} 296$ & E9188 & O6. H16 & A & - & - & - & - & - \\
\hline E8292 & Gambia, 1977 & O6. H16 & A & + & + & + & - & + \\
\hline $58 \mathrm{R} 665$ & E8292 & O6. H16 & A & - & - & - & - & - \\
\hline E5470 & Britain, 1976 & O6. H16 & $\mathrm{C}$ & + & + & - & + & + \\
\hline E219/69 & Sharjah, 1969 & O6. H16 & $\mathrm{C}$ & + & + & - & + & + \\
\hline G176 & E219/69* & O6. H16 & $\mathrm{C}$ & - & - & - & - & - \\
\hline G178 & E3998* & $\mathrm{O} 6 . \mathrm{H} 1$ & NT & - & - & - & - & - \\
\hline
\end{tabular}

$54 \mathrm{R} 310$

$14 \mathrm{R} 519$

Properties

$21 \mathrm{R} 868$

O156. $\mathrm{H}^{-}$fim $\mathrm{Nal}^{\mathrm{r}}$

$\mathrm{K}^{12 \mathrm{~F}^{-}}$lac $\mathrm{Nal}^{\mathrm{r}}$

$\mathrm{K} 12 \mathrm{~F}^{-} \operatorname{lac}^{+} \mathrm{Str}^{\mathrm{r}}$

NT, Not tested.

* Nalidixic acid-resistant mutant.

Table 2. Standard plasmids

\begin{tabular}{llll} 
Plasmid* & $\begin{array}{c}\text { Drug resistance } \\
\text { markers } \dagger\end{array}$ & $\begin{array}{c}\text { Incompatibility } \\
\text { group }\end{array}$ & \multicolumn{1}{c}{ Reference } \\
R100-1 & CmSmSuTc & FII & Jacob et al. (1977) \\
pMR5 & ApKmTc & P & Robinson et al. (1980) \\
NTP2 & SmSu & 2 & McConnell et al. $(1979)$ \\
NTP107 & $\mathrm{Km}$ & MP10 & McConnell et al. (1979)
\end{tabular}

* NTP = non-autotransferring plasmid.

$\dagger$ Abbreviations for drug resistance markers: Ap, ampicillin; Cm, chloramphenicol; Km, kanamycin; Sm, streptomycin; Su, sulphathiazole; Tc, tetracycline.

strain. An antiserum to CS1 was prepared by using PB-176 as the vaccine strain and absorbing the resultant antiserum with E4833. An antiserum to CS3 was prepared by using E4833 as the vaccine strain and absorbing the resultant antiserum with E2047/69. The immunodiffusion tests were performed as described by Cravioto $e t$ al . (1982).

Transfer of plasmids from the wild-type strain. The wild-type strain E9188 was tested for the presence of transfer factors by attempting to mobilize the non-autotransferring resistance plasmids NTP2 and NTP107 (Anderson \& Threlfall, 1974). Plasmids in E9188 were marked with the ampicillin resistance transposon Tn1 using the temperature-sensitive derivative of RP1 (pMR5) (Robinson et al., 1980). The plasmids were then mobilized into $\mathrm{K} 12$ using the $\mathrm{R}$ factor $\mathrm{R} 100-1$.

Marking of plasmids in K12 by transposition and the formation of mutant plasmids. The kanamycin-resistance transposon Tn5 and the tetracycline-resistance transposon Tn10 were inserted into the CFA/II plasmid by the methods previously described (Smith $e$ t al., 1982). A derivative of R 100-1 which no longer coded for tetracycline resistance was used for mobilization of the CFA/II plasmids marked with Tcr. Deletions in the CFA/II plasmid were produced by transposon loss (Smith et al., 1982).

Phage tests and fertility inhibition. Broth cultures of K12 strains carrying a CFA/II plasmid and a derepressed Flike factor R100-1 were tested with phage $\mu 2$ in surface spot tests. Plasmids that cause fertility inhibition $\left(f^{+}\right)$ inhibit synthesis of $\mathrm{F}$ fimbriae by derepressed F-like factors and therefore reduce or abolish visible lysis of the culture by phage $\mu 2$ (Anderson \& Threlfall, 1974).

The ability of $E$. coli $\mathrm{K} 12$ carrying the CFA/II plasmids to restrict $E$. coli phages was tested by using surface spot tests as previously described (McConnell et al., 1980).

Incompatibility experiments. The CFA/II plasmids were tested for their incompatibility relationships, i.e. their ability to co-exist stably with each other. NTP162 was mobilized by R100-1 into a K12 strain carrying NTP166 and the transconjugants tested for loss of drug resistance and MRHA (Table 3; Smith et al., 1983).

Plasmid DNA studies. Plasmid DNA was partially purified from the wild-type strains and from $\mathrm{K} 12$ derivatives. For rapid screening the strains were lysed with alkaline sodium dodecyl sulphate as described by Birnboim \& Doly 
(1979). Molecular weights of the plasmids were determined by electrophoresis on vertical slab gels containing $0.6 \%(\mathrm{w} / \mathrm{v})$ agarose (Sigma type II); plasmids of known molecular weight were run on the same gels.

Enzyme-linked immunosorbent assay (ELISA). (1) Preparation of Immunoglobulin $G(I g G)$. Specific IgGs were precipitated with ammonium sulphate at $33 \%$ saturation. The mixture was allowed to equilibrate for $30 \mathrm{~min}$ at room temperature. After centrifugation at $20000 \mathrm{~g}$ at $4{ }^{\circ} \mathrm{C}$ for $20 \mathrm{~min}$, the pellet was redissolved in a minimal volume of PBS $\left(0 \cdot 15 \mathrm{M}-\mathrm{NaCl}, 0 \cdot 15 \mathrm{M}^{-} \mathrm{PO}_{4}, \mathrm{pH} 7 \cdot 2\right)$. The IgG was then dialysed overnight at $4{ }^{\circ} \mathrm{C}$ against $0 \cdot 01 \mathrm{M}-$ sodium carbonate buffer ( $\mathrm{pH} 9 \cdot 5)$. The protein concentration was read at $A_{280}$.

(2) Preparation of conjugate. The IgG was labelled with horse-radish peroxidase as described by Smith \& Tedder (1981).

(3) Preparation of antigens. The antigens were prepared by two methods, sonication and heat extraction. For sonication the cells were grown overnight on a $150 \mathrm{~mm}$ CFA agar plate (Evans \& Evans, 1978), then resuspended in $10 \mathrm{ml}$ PBS at an approximate concentration of $10^{10}$ cells $\mathrm{ml}^{-1}$. The suspension was then sonicated for $7 \mathrm{~min}$. The cell debris was removed by centrifugation at $30000 \mathrm{~g}$. Samples $(1 \mathrm{ml})$ were kept frozen at $-30{ }^{\circ} \mathrm{C}$. For heat extraction the cells from a CFA agar slope were resuspended in $1 \mathrm{ml}$ saline and heated at $60^{\circ} \mathrm{C}$ for $30 \mathrm{~min}$.

(4) Immunoassay. Microtitre plates were coated with $200 \mu \mathrm{l}$ specific $\mathrm{IgG}$ at a concentration of approximately $4 \mu \mathrm{g} \mathrm{ml}^{-1}$ in carbonate buffer, $\mathrm{pH} 9 \cdot 5$, and left overnight at $4{ }^{\circ} \mathrm{C}$. The plates were washed three times in PBS containing $0.02 \%(\mathrm{v} / \mathrm{v})$ Tween $20(\mathrm{PT})$. Antigen $(100 \mu \mathrm{l})$ was added to each well. The antigens were prepared by heat extraction and used diluted $1: 2$, or prepared by sonication and used in doubling dilutions, in PBS containing $0.01 \%(\mathrm{v} / \mathrm{v})$ Tween 20 and $0.5 \%(\mathrm{v} / \mathrm{v})$ foetal calf serum (PTF). The plates were incubated for $2 \mathrm{~h}$ at $37^{\circ} \mathrm{C}$, and then washed three times in PT. Specific IgG conjugate $(100 \mu \mathrm{l})$ diluted in PTF were added to each well on the plate. The optimum dilution of the conjugate was previously determined by titration against specific antigens. The plates were again incubated for $2 \mathrm{~h}$ at $37{ }^{\circ} \mathrm{C}$ and then washed as before. Substrate $(100 \mu \mathrm{l})$ prepared by adding $9 \mathrm{mg} o-$ phenylenediamine and $40 \mu \mathrm{l} \mathrm{30 \%}$ hydrogen peroxide to $25 \mathrm{ml} 0 \cdot 1 \mathrm{M}$-phosphate buffer $\mathrm{pH} 6.0$, was added to each well and the plates were incubated in the dark at room temperature for $1 \mathrm{~h}$. Sulphuric acid $(0.25 \mathrm{M} ; 25 \mu \mathrm{l})$ was added to each well to stop the reaction. The results were read on an ELISA reader (Titertek Multiskan, Dynatech) at $492 \mathrm{~nm}$. The end point of the titration was taken as the dilution when the reading was five to ten times the level of the control strain.

Electron microscopy. The strains to be used for electron microscopy were grown on CFA agar for two successive $24 \mathrm{~h}$ periods to give maximum expression of CFA/II and suppress the production of type 1 fimbriae (Evans \& Evans, 1978). These strains were examined for type 1 fimbriae by making a suspension of approximately $10^{11}$ cells $\mathrm{ml}^{-1}$ in saline and testing for MSHA. The cells were prepared for electron microscopy and immune electron microscopy according to the methods previously described (McConnell et al., 1981).

\section{RESULTS}

\section{Properties of the wild-type strains used as donors of CFA/II plasmids}

The plasmids used in this study were transferred from two wild-type ETEC strains of serotype O6. H16, E9188 and E5470 (Table 2). Both these strains produced LT and ST, neither was drugresistant or produced colicin. E9188 had previously been shown to belong to biotype $\mathrm{A}$ and produce CFA/II components CS1 and CS3, while E5470 belonged to biotype C and produced CFA/II components CS2 and CS3 (Cravioto et al., 1982). The strains were initially identified by their ability to give MRHA of calf erythrocytes at $4{ }^{\circ} \mathrm{C}$. E9188 also gave weak MRHA of human erythrocytes but E5470 did not. As with calf erythrocytes (Smith et al., 1983), whether or not MRHA occurred depended on the individual from whom the erythrocytes were obtained. The other biotype A strain E8292 used in this study gave very good MRHA with human erythrocytes (Table 1). Strains of biotypes $B, C$ and $F$ had previously been shown not to give any haemagglutination of human erythrocytes (Cravioto et al., 1982; Smith et al., 1983).

E5470 had previously been shown to contain no transfer factors. Only one plasmid (NTP148) of a molecular weight of $59 \times 10^{6}$ was identified by gel electrophoresis (Smith et al., 1983). E9188 was tested for transfer factors as described in Methods, but no mobilization of NTP2 or NTP107 was observed. The strain contained five plasmids of molecular weights 59, 44, 6·1, 4.1 and $3.4 \times 10^{6}$.

\section{Transfer of a CFA/II plasmid}

The single plasmid (NTP148) in the wild-type strain E5470 had previously been marked with the $\mathrm{Ap}^{\mathrm{r}}$ transposon Tn1. The autotransferring F-like factor R100-1 was used to mobilize NTP148-Ap (NTP150) into the K12 strain 14R519 when it was found that insertion of Tn1 into 
Table 3. Properties of CFA/II plasmids and their derivatives

\begin{tabular}{|c|c|c|c|c|c|c|c|c|}
\hline \multirow[b]{2}{*}{$\begin{array}{l}\text { Original } \\
\text { strain }\end{array}$} & \multirow[b]{2}{*}{$\begin{array}{c}\text { Plasmid } \\
\text { no. }\end{array}$} & \multirow{2}{*}{$\begin{array}{c}\text { Drug } \\
\text { resistance } \\
\text { markers }\end{array}$} & \multicolumn{2}{|c|}{ 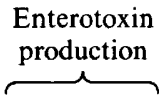 } & \multicolumn{3}{|c|}{$\begin{array}{c}\text { Coli surface } \\
\text { antigen }\end{array}$} & \multirow{2}{*}{$\begin{array}{c}10^{-6} \times \\
\text { Molecular } \\
\text { weight }\end{array}$} \\
\hline & & & sT & $\widehat{\mathrm{LT}}$ & $\mathrm{CS} 1^{*}$ & $\mathrm{CS} 2^{*}$ & $\mathrm{CS3}$ & \\
\hline $\begin{array}{l}\text { E9188 } \\
\text { O6.H16 } \\
\text { biotype A }\end{array}$ & $\begin{array}{l}\text { NTP155 } \\
\text { NTP166 } \\
\text { NTP167 }\end{array}$ & $\begin{array}{l}\overline{\text { Ap }} \\
\text { ApTc }\end{array}$ & $\begin{array}{l}+ \\
+ \\
+\end{array}$ & $\begin{array}{l}+ \\
+ \\
+\end{array}$ & $\begin{array}{l}+ \\
+ \\
+\end{array}$ & $\begin{array}{l}- \\
- \\
-\end{array}$ & $\begin{array}{l}+ \\
+ \\
+\end{array}$ & $\begin{array}{l}59 \\
62 \\
64\end{array}$ \\
\hline $\begin{array}{l}\text { E5470 } \\
\text { O6.H16 } \\
\text { biotype C }\end{array}$ & $\begin{array}{l}\text { NTP148 } \\
\text { NTP150 } \\
\text { NTP157 } \\
\text { NTP161 } \\
\text { NTP162 }\end{array}$ & $\begin{array}{l}\overline{A p} \\
\text { ApKm } \\
\text { ApKm } \\
\text { Km }\end{array}$ & $\begin{array}{l}+ \\
+ \\
+ \\
+ \\
-\end{array}$ & $\begin{array}{l}+ \\
- \\
- \\
-\end{array}$ & $\begin{array}{l}- \\
- \\
- \\
- \\
-\end{array}$ & $\begin{array}{l}+ \\
+ \\
+ \\
+ \\
-\end{array}$ & $\begin{array}{l}+ \\
+ \\
+ \\
+ \\
-\end{array}$ & $\begin{array}{l}59 \\
62 \\
64 \\
64 \\
17\end{array}$ \\
\hline
\end{tabular}

* Property in MRHA-negative derivative of original strain.

NTP148 resulted in loss of LT production so that NTP150 coded for ST and MRHA (Smith et al., 1983).

A similar method was used to try to transfer a plasmid coding for MRHA from E9188. Tn1 was used to mark plasmids in the wild-type strain as described in Methods. R100-1 was introduced into the wild-type strain and then used to mobilize Ap ${ }^{r}$ to 14R519. Ten out of ten Apr transconjugants caused MRHA and carried the R plasmid. In order to determine to which plasmid $\mathrm{Ap}^{\mathrm{r}}$ was linked, a 30 min cross was performed using an $\mathrm{Ap}^{\mathrm{r}} \mathrm{MRHA}^{+}$recombinant. The transconjugants were selected on MacConkey agar plates containing either ampicillin or chloramphenicol. Ten colonies from each selection were tested for $\mathrm{Ap}^{\mathrm{r}}, \mathrm{Cm}^{\mathrm{r}}$ and MRHA.

From the cross eight transconjugants were obtained which were positive for all three markers. However five $\mathrm{Cm}^{\mathrm{r}}$ colonies were found to contain only the $\mathrm{R}$ plasmid $\mathrm{R} 100-1$ and three $\mathrm{Ap}^{\mathrm{r}}$ colonies were negative for $\mathrm{Cm}^{\mathrm{r}}$ showing that $\mathrm{Ap}^{\mathrm{r}}$ was not linked to $\mathrm{R} 100-1$. Four $\mathrm{Ap}^{\mathrm{r}} \mathrm{Cm}^{\mathrm{r}}$ MRHA- colonies were identified showing that a plasmid which did not confer MRHA was marked with $A p^{r}$. A strain carrying one of these plasmids was tested for enterotoxins and found to be negative. All the MRHA ${ }^{+}$transconjugants (eight $\mathrm{Ap}^{\mathrm{r}} \mathrm{Cm}^{\mathrm{r}} \mathrm{MRHA}^{+}$, two $\mathrm{Ap}^{\mathrm{r}} \mathrm{MRHA}{ }^{+}$) were $\mathrm{Ap}^{\mathrm{r}}$ so that it was also possible that the MRHA plasmid was marked with this resistance.

Further short crosses were performed from two $\mathrm{Ap}^{\mathrm{r}} \mathrm{Cm}^{\mathrm{r}} \mathrm{MRHA}{ }^{+}$transconjugants again selecting separately for $\mathrm{Ap}^{\mathrm{r}}$ and $\mathrm{Cm}^{\mathrm{r}}$ colonies. From twenty $\mathrm{Cm}^{\mathrm{r}}$ transconjugants one was obtained which also gave MRHA but was negative for $\mathrm{Ap}^{\mathrm{r}}$, showing that these two properties could be separated. Two Ap ${ }^{r}$ MRHA $^{+}$colonies were obtained without the R plasmid. From one of these, $\mathrm{Ap}^{\mathrm{r}}$ was lost, but the transconjugant was still $\mathrm{MRHA}^{+}$.

The Ap ${ }^{r}$ MRHA $^{+}$transconjugant carried two plasmids of molecular weights 48 and $59 \times 10^{6}$. After loss of $\mathrm{Ap}^{\mathrm{r}}$, the plasmid of molecular weight $59 \times 10^{6}$ (NTP155) was left. Toxin and immunodiffusion tests showed that the K12 strain carrying this plasmid produced LT, ST and CS3, but no CS1 was detected. However, transfer of the marked derivative of NTP155, NTP167 (see next section and Table 3) into a MRHA negative derivative of E9188 (58R296) showed that the plasmid still coded for CS1 as well as CS3, since this strain produced both antigens.

\section{Marking of NTP148 and NTP155 by transposition and isolation of mutants in K12}

NTP148 had been marked with Tn1 in the wild-type strain to give NTP150 with loss of the ability to produce LT (Table 3, Smith et al., 1983). NTP150 was subsequently marked with Tn5 as described in Methods, in two independent experiments, to give CFA/II plasmids coding for Ap, Km and ST, NTP157 and NTP161. A deletion mutant, NTP162, was isolated by loss of Ap ${ }^{r}$ from NTP161 with loss of the ability to produce CS antigens, and ST.

In order to compare the properties of the plasmids from two different biotypes and to examine the expression of the CS antigens in different host strains, NTP155 was marked with Ap ${ }^{r}$ (NTP166) and Ap $\mathrm{Ac}^{\mathrm{r}}$ (NTP167) by transposition as described in Methods (Table 3). 
Table 4. Expression of CS antigens in different host strains

\begin{tabular}{|c|c|c|c|}
\hline \multirow[b]{2}{*}{ Strain } & \multirow[b]{2}{*}{ Test } & \multicolumn{2}{|c|}{ Plasmid no.: } \\
\hline & & NTP167 & NTP157 \\
\hline $\begin{array}{l}\text { O6. H16 } \\
\text { biotype A } \\
\text { 58R296 }\end{array}$ & $\begin{array}{l}\text { MRHA Calf RBC } \\
\text { Human RBC } \\
\text { ID and ELISA }\end{array}$ & $\begin{array}{l}++++ \\
+ \\
\text { CS1, CS3 }\end{array}$ & $\begin{array}{l}++++ \\
+ \\
\text { CS1, CS3 }\end{array}$ \\
\hline $\begin{array}{l}\text { O6. H16 } \\
\text { biotype A } \\
58 \mathrm{R} 665\end{array}$ & $\begin{array}{l}\text { MRHA Calf RBC } \\
\text { Human RBC } \\
\text { ID and ELISA }\end{array}$ & $\begin{array}{l}++++ \\
++++ \\
\operatorname{CS} 1, \operatorname{CS} 3\end{array}$ & $\begin{array}{l}++++ \\
+++ \\
\operatorname{CS} 1, \operatorname{CS} 3\end{array}$ \\
\hline $\begin{array}{l}\text { O6.H16 } \\
\text { biotype C } \\
\text { G176 }\end{array}$ & $\begin{array}{l}\text { MRHA Calf RBC } \\
\text { Human RBC } \\
\text { ID and ELISA }\end{array}$ & $\begin{array}{l}+++ \\
- \\
\operatorname{cs} 2, \operatorname{cs} 3\end{array}$ & $\begin{array}{l}+++ \\
- \\
\operatorname{CS} 2, \operatorname{CS} 3\end{array}$ \\
\hline $\begin{array}{c}\mathrm{O} 6 . \mathrm{H} 1 \\
\mathrm{G} 178\end{array}$ & $\begin{array}{l}\text { MRHA Calf RBC } \\
\text { ID and ELISA }\end{array}$ & $\stackrel{+}{\mathrm{CS} 3}$ & $\overline{\mathrm{CS}} 3$ \\
\hline $\begin{array}{l}\text { O156. H- } \mathrm{fim} \\
\text { 54R310 }\end{array}$ & $\begin{array}{l}\text { MRHA Calf RBC } \\
\text { ID and ELISA }\end{array}$ & $\begin{array}{l}++ \\
\operatorname{CS} 3\end{array}$ & $\stackrel{+}{\mathrm{CS} 3}$ \\
\hline $\begin{array}{c}E . \text { coli K12 } \\
21 \mathrm{R} 868\end{array}$ & $\begin{array}{c}\text { MRHA Calf RBC } \\
\text { Human RBC } \\
\text { ID and ELISA }\end{array}$ & $\begin{array}{l}++ \\
\overline{\operatorname{cs} 3}\end{array}$ & $\frac{+}{\operatorname{cs} 3}$ \\
\hline
\end{tabular}

\section{Properties of these plasmids}

These are listed in Table 3. NTP150 and NTP166 were mainly used to examine the genetic properties of the two plasmids. Strains carrying both plasmids gave fertility inhibition of $\mu 2$ phage but did not restrict any of the range of phages described in Methods. Both were nonautotransferring and were mobilized by F-like R plasmids. R100-1 mobilized NTP150 and NTP166 into K12 in an $18 \mathrm{~h}$ cross at a frequency of $10^{-1}$ to $10^{-2}$ per recipient cell, but with other F-like R plasmids the frequency of transfer was lower (Smith et al., 1983). Incompatibility tests showed that NTP162, a $\mathrm{CS}^{-} \mathrm{CS}_{3}{ }^{-} \mathrm{ST}^{-}$derivative of NTP150, and NTP166 were incompatible with each other and belonged to Inc group FI.

\section{Expression of plasmids in different host strains}

Previous work had shown that $\mathrm{K} 12, \mathrm{O} 8 . \mathrm{H} 9, \mathrm{O} 25 . \mathrm{H} 42$ and $\mathrm{O} 78 . \mathrm{H}^{-}$strains containing NTP150 only expressed one CFA/II component, CS3 (Smith et al., 1983). NTP167 and NTP157 were mobilized into a number of different recipient strains. Transconjugants which did not contain the $\mathbf{R}$ factor were examined for MRHA of calf and human erythrocytes and by immunodiffusion and ELISA. The results are shown in Table 4.

When NTP157 and NTP167 were transferred to O156. H- $^{-}$O6.H1 or K12 strains, only one CFA/II component, CS3, was expressed. In O6.H16 strains, CS3 was also expressed along with another antigen CS1 or CS2. Which of these latter antigens was produced depended on the biotype of the host; biotype A strains expressed CS1 and biotype C strains CS2 in addition to CS3. NTP157 was also transferred to O6.H16 strains of biotype B and F when CS2 and CS3 were expressed (results not shown).

Strains which only produced CS3 gave a very weak haemagglutination with calf erythrocytes and none with human erythrocytes. The strains producing CS1 or CS2 as well as CS3 gave much better haemagglutination than $\mathrm{CS} 3$ only strains. The $\mathrm{CS}_{1}^{+}, \mathrm{CS}^{+}$strains gave the best haemagglutination. $\mathrm{CSI}^{+}, \mathrm{CS}^{+}$strains also caused haemagglutination of human erythrocytes, although the degree of haemagglutination varied with the host strain, while $\mathrm{CS} 2{ }^{+} \mathrm{CS} 3{ }^{+}$strains did not cause any haemagglutination of these erythrocytes (Table 4).

\section{Titration of CS antigen production}

The amount of the CS antigens produced by different strains carrying the two plasmids NTP167 and NTP157 when they were present in different host strains was compared using the 
Table 5. Production of CS antigens as measured by ELISA

\begin{tabular}{|c|c|c|c|c|}
\hline \multirow[b]{2}{*}{ Host strain } & \multirow[b]{2}{*}{ Plasmid } & \multicolumn{3}{|c|}{ Production of antigen ${ }^{*}$} \\
\hline & & CS1 & CS2 & $\mathrm{CS} 3$ \\
\hline $\begin{array}{l}\text { O6.H16 } \\
\text { biotype A } \\
\text { 58R296 }\end{array}$ & $\begin{array}{l}\text { NTP167 } \\
\text { NTP157 }\end{array}$ & $\begin{array}{l}2^{10} \\
2^{11}\end{array}$ & $\begin{array}{l}\text { NAD } \\
\text { NAD }\end{array}$ & $\begin{array}{l}2^{10} \\
2^{5}\end{array}$ \\
\hline $\begin{array}{l}\text { O6. H16 } \\
\text { biotype C } \\
\text { G176 }\end{array}$ & $\begin{array}{l}\text { NTP167 } \\
\text { NTP157 }\end{array}$ & $\begin{array}{l}\text { NAD } \\
\text { NAD }\end{array}$ & $\begin{array}{l}2^{11} \\
2^{11}\end{array}$ & $\begin{array}{l}2^{15} \\
2^{11}\end{array}$ \\
\hline $\begin{array}{l}\mathrm{O}_{5456 . \mathrm{H}^{-}} \mathrm{fim} \\
\end{array}$ & $\begin{array}{l}\text { NTP167 } \\
\text { NTP157 }\end{array}$ & $\begin{array}{l}\text { NAD } \\
\text { NAD }\end{array}$ & $\begin{array}{l}\text { NAD } \\
\text { NAD }\end{array}$ & $\begin{array}{l}2^{11} \\
2^{11}\end{array}$ \\
\hline $\begin{array}{c}\text { E. coli } \mathrm{K} 12 \\
21 \mathrm{R} 868\end{array}$ & $\begin{array}{l}\text { NTP167 } \\
\text { NTP157 }\end{array}$ & $\begin{array}{l}\text { NAD } \\
\text { NAD }\end{array}$ & $\begin{array}{l}\text { NAD } \\
\text { NAD }\end{array}$ & $\begin{array}{l}2^{16} \\
2^{11}\end{array}$ \\
\hline
\end{tabular}

NAD, No antigen detected.

* The CS titre was expressed as the highest dilution which gave a reading five to ten times that of the control.

Table 6. Electron microscopy of strains containing CFA/II plasmids

\begin{tabular}{|c|c|c|c|c|c|c|c|}
\hline \multirow[b]{2}{*}{ Strain } & \multirow[b]{2}{*}{ Plasmid } & \multirow{2}{*}{$\begin{array}{l}\text { Antigens } \\
\text { produced }\end{array}$} & \multirow{2}{*}{$\begin{array}{l}\text { No. of } \\
\text { cells } \\
\text { counted }\end{array}$} & \multicolumn{3}{|c|}{$\begin{array}{l}\text { No. of cells } \\
\text { with degree of } \\
\text { fimbriation* }\end{array}$} & \multirow{2}{*}{$\begin{array}{c}\text { Percentage } \\
\text { fimbriate }\end{array}$} \\
\hline & & & & Many & Moderate & Few & \\
\hline $\begin{array}{l}\text { O6. H16 } \\
\text { biotype A } \\
\text { 58R296 }\end{array}$ & $\begin{array}{l}\text { None } \\
\text { NTP167 } \\
\text { NTP157 }\end{array}$ & $\begin{array}{l}\text { None } \\
\text { CS1, CS3 } \\
\text { CS1, CS3 }\end{array}$ & $\begin{array}{l}212 \\
175 \\
109\end{array}$ & $\begin{array}{r}0 \\
89 \\
91\end{array}$ & $\begin{array}{r}0 \\
38 \\
0\end{array}$ & $\begin{array}{r}0 \\
25 \\
1\end{array}$ & $\begin{array}{r}0 \\
87 \\
84\end{array}$ \\
\hline $\begin{array}{l}\text { O6. H16 } \\
\text { biotype C } \\
\text { G176 }\end{array}$ & $\begin{array}{l}\text { None } \\
\text { NTP167 } \\
\text { NTP157 }\end{array}$ & $\begin{array}{l}\text { None } \\
\text { CS2, CS3 } \\
\text { CS2, CS3 }\end{array}$ & $\begin{array}{l}246 \\
147 \\
115\end{array}$ & $\begin{array}{r}0 \\
73 \\
70\end{array}$ & $\begin{array}{r}2 \\
45 \\
45\end{array}$ & $\begin{array}{r}4 \\
18 \\
0\end{array}$ & $\begin{array}{c}2 \cdot 5 \\
92 \\
100\end{array}$ \\
\hline $\begin{array}{l}\text { O156. } \mathrm{H}^{-} \text {fim } \\
\text { 54R310 }\end{array}$ & $\begin{array}{l}\text { None } \\
\text { NTP167 } \\
\text { NTP157 }\end{array}$ & $\begin{array}{l}\text { None } \\
\text { CS3 } \\
\text { CS3 }\end{array}$ & $\begin{array}{l}608 \\
167 \\
480\end{array}$ & $\begin{array}{l}6 \\
2 \\
0\end{array}$ & $\begin{array}{l}1 \\
0 \\
0\end{array}$ & $\begin{array}{l}2 \\
2 \\
2\end{array}$ & $\begin{array}{l}1 \cdot 5 \\
2 \cdot 5 \\
0 \cdot 5\end{array}$ \\
\hline $\begin{array}{l}\text { E. coli K12 } \\
\text { 21R868 }\end{array}$ & $\begin{array}{l}\text { None } \\
\text { NTP166 } \\
\text { NTP150 }\end{array}$ & $\begin{array}{l}\text { None } \\
\text { CS3 } \\
\text { CS3 }\end{array}$ & $\begin{array}{l}173 \\
130 \\
104\end{array}$ & $\begin{array}{r}\text { NT } \\
2 \\
2\end{array}$ & $\begin{array}{r}\text { NT } \\
0 \\
0\end{array}$ & $\begin{array}{r}\text { NT } \\
0 \\
2\end{array}$ & $\begin{array}{l}9 \\
1 \cdot 5 \\
3 \cdot 8\end{array}$ \\
\hline
\end{tabular}

NT, Not tested.

* Many, > 200 fimbriae per cell; moderate, 20-200 fimbriae per cell; few, <20 fimbriae per cell.

ELISA (Table 5). This assay was only semi-quantitative but was very sensitive for the detection of the antigens; CS1 and CS2 could be detected at a dilution up to $2^{15}$.The tests for CS1 and CS2 with extracts of $\mathrm{O} 156 . \mathrm{H}^{-}$or $\mathrm{K} 12$ strains carrying the plasmids were completely negative, while CS3 production occurred at a similar level or higher than that in the O6 strains. Strains carrying NTP167 usually produced more CS3 than the corresponding strain carrying NTP157. The experiments also showed that there was no apparent cross-reaction between any of the antigens.

\section{Electron microscopy}

For these experiments strains carrying the plasmids marked with two resistances NTP167 and NTP157 were used except for K12 strains which carried the plasmids with one drugresistance marker NTP166 and NTP150. Examination of negatively-stained preparations of cultures by electron microscopy showed that strains without plasmids coding for any CFA/II antigens were mainly non-fimbriate (Table 6). Strains producing CS1 or CS2 consisted mainly of fimbriate cells, while cultures which only produced CS3 were mainly non-fimbriate like the original host strain. The few fimbriae seen on cells devoid of CS1 and CS2 antigens were 

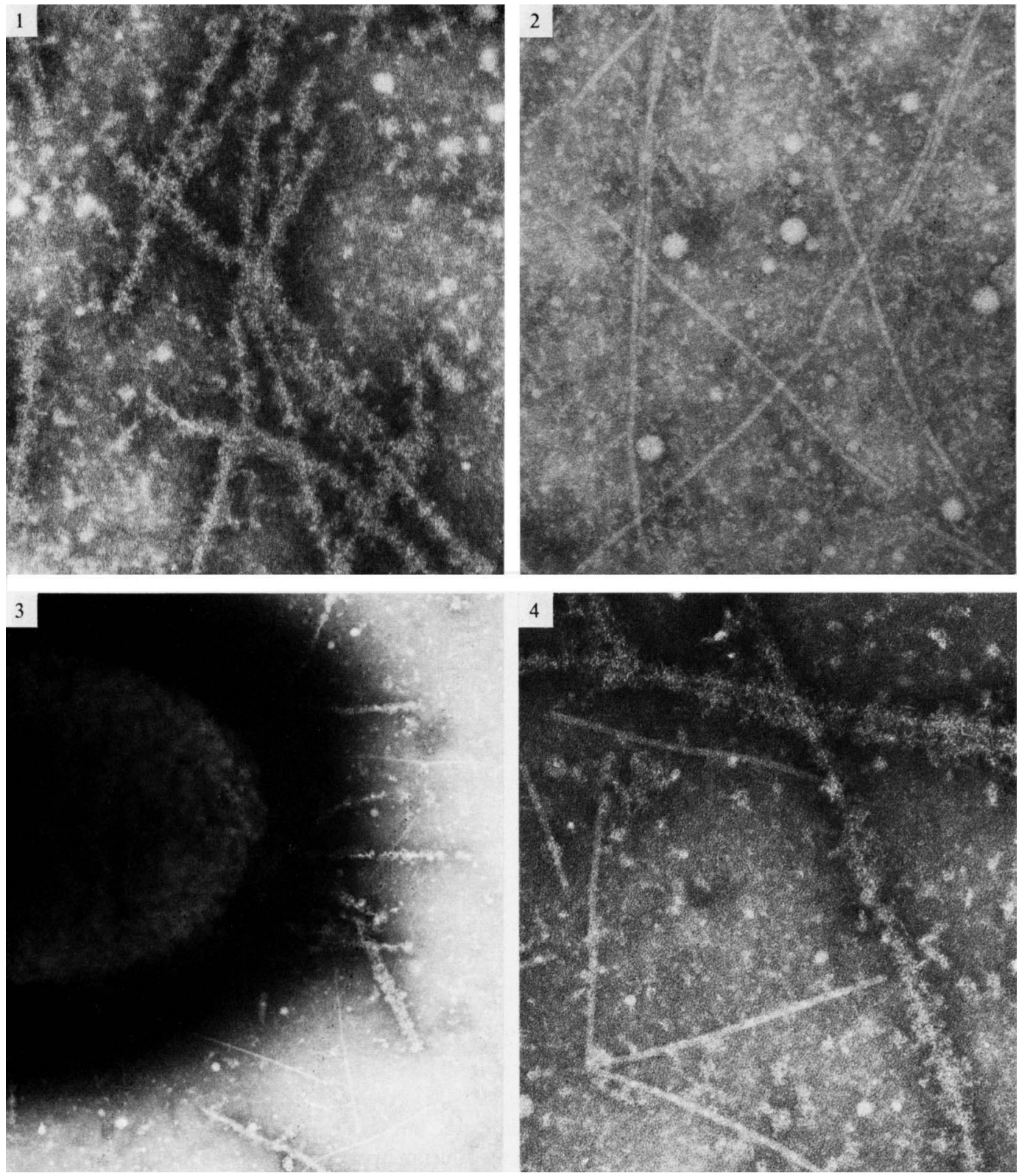

Fig. 1. Fimbriae from G176 with NTP157, expressing CS2 and CS3 antigens, treated with CS2 antiserum. The fimbriae are heavily coated with antibody. Negative stain $\times 150000$.

Fig. 2. Fimbriae from G176 with NTP157, expressing CS2 and CS3 antigens, treated with CS1 antiserum. The fimbriae are not coated with antibody. Negative stain $\times 150000$.

Fig. 3. 58R296 with NTP167, expressing CS1 and CS3 antigens, treated with CS1 antiserum. All the fimbriae attached to the bacterium and some of the loose fimbriae are heavily coated with antibody; other loose fimbriae are not coated. Negative stain $\times 48000$.

Fig. 4. Fimbriae from 58R296 with NTP167, expressing CS1 and CS3 antigens, treated with CS1 antiserum. Some loose fimbriae are heavily coated with antibody and others are not coated. Negative stain $\times 150000$. 
Table 7. Immune electron microscopy

\begin{tabular}{|c|c|c|c|}
\hline \multirow[b]{2}{*}{ Strain } & \multirow[b]{2}{*}{ Serum } & \multicolumn{2}{|c|}{ Plasmid no. } \\
\hline & & NTP167 & NTP157 \\
\hline $\begin{array}{l}\text { O6. H16 } \\
\text { biotype A } \\
58 \text { R296 }\end{array}$ & $\begin{array}{l}\text { Anti-CS1 } \\
\text { Anti-CS2 } \\
\text { Anti-CS3 }\end{array}$ & $\begin{array}{c}++1- \\
- \\
-\end{array}$ & $\begin{array}{c}++1- \\
- \\
-\end{array}$ \\
\hline $\begin{array}{l}\text { O6. H16 } \\
\text { biotype C } \\
\text { G176 }\end{array}$ & $\begin{array}{l}\text { Anti-CS1 } \\
\text { Anti-CS2 } \\
\text { Anti-CS3 }\end{array}$ & $\begin{array}{c}- \\
++ \\
-\end{array}$ & $\begin{array}{c}-\overline{+}+ \\
-\end{array}$ \\
\hline $\begin{array}{c}\text { E. coli K12 } \\
21 \mathrm{R} 868\end{array}$ & $\begin{array}{l}\text { Anti-CS1 } \\
\text { Anti-CS2 } \\
\text { Anti-CS3 }\end{array}$ & $\begin{array}{l}\text { NT } \\
\text { NT } \\
\text { NT }\end{array}$ & $\begin{array}{l}\text { NT } \\
-\end{array}$ \\
\hline
\end{tabular}

NT, Not tested.

+++ , fimbriae heavily coated with antibody; - , fimbriae not coated with antibody; $+++/-$, attached fimbriae and some loose fimbriae heavily coated with antibody, some loose fimbriae not coated with antibody.

probably type 1 fimbriae which have previously been seen on cells grown in these culture conditions (McConnell et al., 1981). The antigenic nature of the fimbriae was investigated in some strains by immune electron microscopy using CS1, CS2 and CS3 antisera to coat the fimbriae on the cells. It was seen that CS1 and CS2 antibodies attached only to fimbriae of cells producing the homologous antigens (Figs 1 and 2; Table 7). Immune electron microscopy failed to identify any binding site for CS3 antibody on the cell body, on the few fimbriae observed on cells producing only CS3, or on the fimbriae produced by strains exhibiting CS1 and CS3 or CS2 and CS3. The CS1 and CS2 fimbriae were morphologically indistinguishable and measured approximately $6.5 \mathrm{~nm}$ in width. The CS2 antibody coated all attached and loose fimbriae in cultures of cells producing CS2, but it was found that CS1 antibody failed to coat some of the loose fimbriae in cultures of cells producing CS1 while coating all attached fimbriae (Figs 3 and 4).

\section{DISCUSSION}

The experiments described show that the plasmids coding for CFA/II, ST and LT found in $E$. coli $\mathrm{O6}$. H16 strains of different biotypes are very similar. The important factor determining which CFA/II component, CS1 or CS2, is produced is the genetic character of the host strain which is recognized by its biotype. The biotype of the $06 . \mathrm{H} 16$ strain is probably not important per se in determining which CS antigen is produced, since strains of biotypes $\mathrm{B}, \mathrm{C}$ and $\mathrm{F}$ all produce CS2, but the chromosomal genes which influence whether CS1 or CS2 are produced have not been identified. When the same plasmids are transferred to strains of other serotypes such as $\mathrm{O} 6 . \mathrm{H} 1, \mathrm{O} 156 . \mathrm{H}^{-}, \mathrm{O} 8 . \mathrm{H} 9$ and $E$. coli $\mathrm{K} 12$, only $\mathrm{CS} 3$ is expressed. The only other serotype we have found which expresses CS1 as well as CS3 is a single O139. H28 strain isolated in Egypt. Another strain of this serotype produces CS3 only and not CS1 or CS2 when carrying a CFA/II plasmid (M. M. McConnell \& S. M. Scotland, unpublished).

Since transfer of a CFA/II plasmid to strains of serotypes other than O6.H16 gives strains which produce only CS3, we have been able to look at the properties of the CS3 antigen separately and compare these with those of strains carrying both antigens. Electron microscopy shows that $\mathrm{CS} 3$ is non-fimbrial; therefore the fimbriae seen on $\mathrm{CS}_{1}{ }^{+} \mathrm{CS} 3{ }^{+}$or $\mathrm{CS} 2{ }^{+} \mathrm{CS} 3{ }^{+}$ strains are the CS1 and CS2 antigens. The haemagglutination obtained with CS3-producing strains and calf blood was always very poor. With erythrocytes from some calves no haemagglutination was seen. This might explain why Smyth (1982) did not consider CS3 to be a haemagglutinin. Strains producing CS1 gave good haemagglutination of calf erythrocytes. Strains producing CS2 gave different degrees of haemagglutination from very good to none at all with erythrocytes from different calves (unpublished work; Faris et al., 1982). Several reports 
have said that CFA/II strains do not haemagglutinate human erythrocytes (Ørskov \& Ørskov, 1977; Evans \& Evans, 1978; Smyth, 1982), while we have found that strains producing CS1 frequently do, once again the result depends on the particular human erythrocytes used (unpublished work; Cravioto et al., 1982).

In a survey of $E$. coli of different serotypes and from a variety of sources it was found that many strains possessed surface haemagglutinins which could bind erythrocytes. The ability of strains to cause MRHA or MSHA was usually associated with the presence of fimbriae. However, a few strains were found which caused MRHA but did not possess fimbriae (Duguid et al., 1979; Ip et al., 1981). The adhesion and ability to cause MRHA of some porcine ETEC was also mediated by non-fimbriate material (Awad-Masalmeh et al., 1982). A mannosespecific lectin has been isolated from an $E$. coli strain causing a urinary tract infection which agglutinates yeast cells and human epithelial cells and differs from the fimbrial type 1 protein (Eshdat et al., 1978). The O6 strains we have examined cause MRHA by fimbrial and nonfimbrial antigens, while the CFA/II strains of other serogroups only form the non-fimbrial antigen.

We have not been able to detect any cross-reaction between CS1 and CS2 by ELISA or immune electron microscopy. It may be that two structural genes are present on CFA/II plasmids which are switched on separately in different hosts, or one structural gene may be present and the gene product may be modified differently in the two hosts to produce antigenically distinct fimbriae. DNA and amino-acid sequencing should help to distinguish these two possibilities.

The presence of loose fimbriae to which no antibody was attached when they were treated with CS1 antiserum suggested that these $\mathrm{O6}$ strains were producing a small number of fimbriae which differed antigenically from the much larger number of CS1 fimbriae formed. The strain might be producing type 1 fimbriae, although none were observed when the control strain was examined. The nature of these fimbriae is being investigated.

The results of antigen testing obtained by immunodiffusion were confirmed by ELISA. However, this test has been shown to be more sensitive than immunodiffusion. Strains carrying one mutant plasmid NTP156 were originally found to be negative for CS3 by immunodiffusion tests. ELISA titrations showed that some CS3 was coded for by this plasmid, although it was less than the wild-type strain (results not shown).

An 08.H9 strain which only produces CS3 has been shown to attach to human intestinal epithelial cells (Wadstrom et al., 1980) suggesting that CS3 is an adhesin (Smyth, 1982). O6.H16 strains produce this antigen as well as the CS1 or CS2 fimbriae so that it is not clear if the fimbriae are required for adherence. The role of these fimbriae in pathogenicity requires testing using strains which do not produce CS3.

\section{REFERENCES}

Anderson, E. S. \& Threlfall, E. J. (1974). The characterisation of plasmids in the enterobacteria. Journal of Hygiene 72, 471-487.

Awad-Masalmeh, A., Moon, H. W., Runnels, P. L. \& SCHNEIDER, R. A. (1982). Pilus production, hemagglutination and adhesion by porcine strains of enterotoxigenic Escherichia coli lacking K88, K99, and 987P antigens. Infection and Immunity 35, 305313.

Birnboim, H. C. \& Doly, J. (1979). A rapid alkaline extraction procedure for screening recombinant plasmid DNA. Nucleic Acids Research 7, 1513-1523.

Cravioto, A., Scotland, S. M. \& Rowe, B. (1982). Hemagglutination activity and colonization factor antigens I and II in enterotoxigenic and nonenterotoxigenic strains of Escherichia coli isolated from humans. Infection and Immunity 36, 189-197.

Dean, A. G., Ching, Y.-C., Williams, R. G. \&
HARDEN, L. B. (1972). Test for Escherichia coli enterotoxin using infant mice. Application in a study of diarrhoea in children in Honolulu. Journal of Infectious Diseases 125, 407-411.

DonTA, S. T., Moon, H. W. \& WhIPP, S. C. (1974). Detection of heat-labile Escherichia coli enterotoxin with the use of adrenal cells in tissue culture. Science 183, 334-336.

Duguid, J. P., Smith, I. W., Dempster, G. \& EDMUNDS, P. N. (1955). Non-flagellar filamentous appendages (fimbriae) and haemagglutinating activities in Bacterium coli. Journal of Pathology and Bacteriology 70, 335-348.

Duguid, J. P., ClegG, S. \& Wilson, M. I. (1979). The fimbrial and non-fimbrial haemagglutinins of $E s-$ cherichia coli. Journal of Medical Microbiology 12 , 213-227.

Eshdat, Y., Ofex, I., Yashouv-Gan, Sharon, N. \& 
Mirelman, D. (1978). Isolation of a mannosespecific lectin from Escherichia coli and its role in the adherence of the bacteria to epithelial cells. Biochemical and Biophysical Research Communications 85, 1551-1559.

Evans, D. G. \& Evans, D. J. (1978). New surfaceassociated heat-labile colonization factor antigen (CFA/II) produced by enterotoxigenic Escherichia coli of serogroups $\mathrm{O} 6$ and $\mathrm{O8}$. Infection and Immunity 21, 638-647.

Evans, D. G., Silver, R. P., Evans, D. J., Chase, D. G. \& GoRBACH, S. L. (1975). Plasmid-controlled colonization factor associated with virulence in Escherichia coli enterotoxigenic for humans. Infection and Immunity 12, 656-667.

Faris, A., Sellei, J., Lindahl, M. \& Wadstrom, T. (1982). Haemagglutination of bovine erythrocytes by enterotoxigenic $E$. coli (ETEC) of O6 serogroup: evidence for glycoconjugate receptor heterogeneity. Zentralblatt für Bakteriologie, Mikrobiologie und $\mathrm{Hy}$ giene 253, 175-182.

GaAstra, W. \& DE GraAF, F. K. (1982). Host-specific fimbrial adhesins of non-invasive enterotoxigenic Escherichia coli strains. Microbiological Reviews 46, 129-161.

Guerrant, R. L., Brunton, L. L., Schnaitman, T. C., Rebhun, L. I. \& Gilman, A. G. (1974). Cyclic adenosine monophosphate and alteration of Chinese hamster ovary cell morphology: a rapid sensitive in vitro assay for the enterotoxins of Vibrio cholerae and Escherichia coli. Infection and Immunity 10, 320-327.

IP, S. M., Crichton, P. B., Old, D. C. \& Duguid, J. P. (1981). Mannose-resistant and eluting haemagglutinins and fimbriae in Escherichia coli. Journal of Medical Microbiology 14, 223-226.

JaCob, A. E., Shapiro, J. A., Yamamoto, L., SMith, D. I., Cohen, S. N. \& Berg, D. (1977). Plasmids studied in Escherichia coli and other enteric bacteria. In DNA Insertion Elements, Plasmids and Episomes, pp. 607-704. Edited by A. I. Bukhari, J. A. Shapiro \& S. L. Adhya. Cold Spring Harbor, New York: Cold Spring Harbor Laboratory.

McConnell, M. M., Willshaw, G. A., Smith, H. R., SCotland, S. M. \& Rowe, B. (1979). Transposition of ampicillin resistance to an enterotoxin plasmid in an Escherichia coli strain of human origin. Journal of Bacteriology 139, 346-355.

McConnell, M. M., SMith, H. R., WillshaW, G. A., Scotland, S. M. \& Rowe, B. (1980). Plasmids coding for heat-labile enterotoxin production isolated from Escherichia coli O78: comparison of properties. Journal of Bacteriology 143, 158-167.

MCConNell, M. M., SMITH, H. R., WillshaW, G. A., FIELD, A. M. \& Rowe, B. (1981). Plasmids coding for colonization factor antigen I and heat-stable enterotoxin production isolated from enterotoxigenic Escherichia coli: comparison of their properties. Infection and Immunity 32, 927-936.

ØRSKov, I. \& ØRSKOV, F. (1977). Special O :K:H serotypes among enterotoxigenic $E$. coli strains from diarrhea in adults and children. Medical Microbiology and Immunology 163, 99-110.

Penaranda, M. E., ManN, M. B., Evans, D. G. \& Evans, D. J. (1980). Transfer of an ST :LT :CFA/II plasmid into Escherichia coli $\mathrm{K}-12$ strain RRl by cotransformation with pSC301 plasmid DNA. FEMS Microbiology Letters 8, 251-254.

Robinson, M. K., BenNett, P. M., FALkow, S. \& DoDD, H. M. (1980). Isolation of a temperaturesensitive derivative of RP1. Plasmid 3, 343-347.

Scotland, S. M., Gross, R. J. \& Rowe, B. (1977). Serotype-related enterotoxigenicity in Escherichia coli O6. H16 and O148. H28. Journal of Hygiene 79, 395-403.

SMITH, A. M. \& TEDDER, R. S. (1981). Development of an enzyme-linked immunosorbent assay (ELISA) for hepatitis $\mathrm{B}_{\mathrm{e}}$ antigen and antibody. Journal of Virological Methods 3, 1-11.

Smith, H. R., Willshaw, G. A. \& Rowe, B. (1982). Mapping of a plasmid, coding for colonization factor antigen $I$ and heat-stable enterotoxin production, isolated from an enterotoxigenic strain of Escherichia coli. Journal of Bacteriology 149, 264-275.

Smith, H. R., Scotland, S. M. \& Rowe, B. (1983). Plasmids coding for production of colonization factor antigen II and enterotoxin production in strains of Escherichia coli. Infection and Immunity 40 1236-1239.

SMYTH, C. J. (1982). Two mannose-resistant haemagglutinins of enterotoxigenic Escherichia coli of serotype $06: \mathrm{K} 15: \mathrm{H} 16$ or $\mathrm{H}^{-}$isolated from travellers' and infantile diarrhoea. Journal of General Microbiology 128, 2081-2096.

THOMAS, L. V. \& Rowe, B. (1982). The occurrence of colonization factors (CFA/I, CFA/II and E8775) in enterotoxigenic Escherichia coli from various countries in South East Asia. Medical Microbiology and Immunology 171, 85-90.

Thomas, L. V., Cravioto, A., Scotland, S. M. \& Rowe, B. (1982). A new fimbrial antigenic type (E8775) which may represent a colonization factor in enterotoxigenic Escherichia coli in humans. Infection and Immunity 35, 1119-1124.

Wadstrom, T., Faris, A., Freer, J., Habte, D., HallberG, D. \& LJUNGH, A. (1980). Hydrophobic surface properties of enterotoxigenic $E$. coli (ETEC) with different colonization factors (CFA/I, CFA/II, K88 and K99) and attachment to intestinal epithelial cells. Scandinavian Journal of Infectious Diseases Supplement 24, 148-153. 